\title{
Molar Incisor Hypomineralization: the use of Digital Smile Design (DSD) in the Esthetic and Functional Recovery of Teeth
}

\section{Hipomineralização de Molar e Incisivo: o Uso do Desenho Digital do Sorriso na Recuperação Estética e Funcional}

\author{
Suelem Chasse Barreto*a; Victor Vinícius Barros Soares ${ }^{\mathrm{b}}$; Aline de Almeida Neves ${ }^{\mathrm{c}}$; Denise Fernandes Lopez \\ Nascimento ; Lucianne Cople Maiac; Gisele Damiana da Silveira Pereira ${ }^{\mathrm{d}}$
}

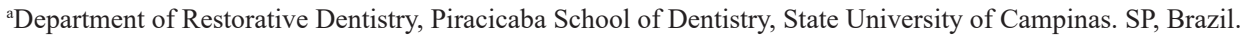

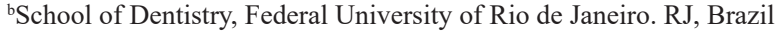 \\ 'Department of Pediatric Dentistry and Orthodontics, School of Dentistry, Federal University of Rio de Janeiro. RJ, Brazil. \\ ${ }^{d}$ Department of Clinical Dentistry, School of Dentistry, Federal University of Rio de Janeiro. RJ, Brazil. \\ *E-mail: suchasse@yahoo.com.br \\ Recebido em: 28/03/2020 \\ Aprovado em: 11/05/2020
}

\begin{abstract}
Hypomineralized incisor molar syndrome (MIH) results from the action of various etiological factors during the enamel apposition and mineralization stages during dental development. Clinically, it results in changes in the shape, color and contour of the affected teeth, which compromises aesthetics and function. Through a clinical case, this study aimed to report the planning, with the aid of digital smile design (DSD), and the restorative treatment, with ceramic laminate ceramic veneers, of anterior teeth affected by MIH. To provide personalized treatment to the patient's needs and expectations, the use of DSD in case planning to a correct diagnosis, simulation and evaluation of aesthetic rehabilitation. It also favored communication between the patient and the multidisciplinary dental team, and this with the laboratory technician.
\end{abstract} Keywords: Dental Enamel Hypoplasia. Dental Porcelain. Esthetics, Dental.

\section{Resumo}

A sindrome do molar incisivo hipomineralizado (MIH), é resultante da ação de vários fatores etiológicos durante os estágios de aposição e mineralização do esmalte, durante o desenvolvimento dental. Clinicamente, resulta em alterações na forma, cor e contorno dos dentes afetados, o que compromete a estética e função. Através de um caso clínico, este trabalho teve como objetivo relatar o planejamento, com auxilio do desenho digital do sorriso (DSD), e o tratamento restaurador, com facetas de cerâmicas de dentes anteriores afetados por MIH. Para proporcionar um tratamento personalizado às necessidades e expectativas da paciente, o DSD foi utilizado no planejamento do caso para o correto diagnóstico, simulação e avaliação da reabilitação estética. Também favoreceu a comunicação entre a paciente e a equipe odontológica multidisciplinar, e desta com o técnico de laboratório.

Palavras-chave: Hipoplasia do Esmalte Dentário. Porcelana Dentária. Estética Dentária

\section{Introduction}

Increasing numbers of patients are requesting cosmetic dental procedures to achieve the perfect smile. ${ }^{1-3}$ In the modern practice of dentistry, it is no longer acceptable to modify isolated teeth. It is imperative that clinicians appreciate the components of a smile to create a final appearance that is not only physiologically and mechanically sound, but also esthetically pleasing. ${ }^{3,4}$

Molar Incisor Hypomineralization (MIH) is a developmental disturbance affecting dental enamel and resulting in defects that may compromising at least one of four permanent first molars, and when the permanent incisors are also affected, the condition is considered severe..$^{5-7}$ The teeth affected show clearly demarcated opacities on the occlusal and buccal surfaces and the enamel is generally discolored, covered by stains that vary from creamy-white to yellow-dark brown, along with disintegration. ${ }^{5}$ In fact, hypomineralization leads to softness and friability, causing loss of tissue, and consequent morphological modifications in shape, size, and contour of the teeth affected. ${ }^{5-7}$ The restoration of these defects is very important not only for esthetic and functional concerns, but also because there may be a positive psychological impact on the patient's quality of life. ${ }^{8}$

During treatment planning, various factors should be considered, such as the patient's age and socioeconomic situation, type and severity of the disorder, and the intraoral and occlusal conditions. In such instances, an interdisciplinary approach is necessary to evaluate, diagnose, and solve functional and esthetic problems. ${ }^{9,10}$ Achieving a successful healthy and functional result requires understanding the interrelationship among all supporting oral structures, including the analysis of smile and teeth, temporomandibular joints, occlusion, and periodontal tissues. ${ }^{11,12}$ Thus, the treatment frequently requires a multidisciplinary team and the use of advanced digital resources, such as the Digital 
Smile Design (DSD), in order to plan the case and recover dental harmony. ${ }^{9-11,13,14}$

The DSD technique uses resources such as digital photographs, study model, diagnostic wax-up, and intraoral restorative testing. ${ }^{4,14,15}$ The association of these tools enables visualizing and evaluating the results before the treatment, providing patients with a preview of their smile and preventing potential difficulties. This ensures a final treatment with a higher chance of esthetic and functional success. ${ }^{4}$ Therefore, this study aimed to report a clinical case of a patient with MIH and deficient composite restorations, in which the treatment included the DSD technique to plan the esthetic rehabilitation of anterior teeth with ceramic veneers.

\section{Case Report}

A 22-year-old female patient was attended at School of Dentistry with the chief complaint of poor smile esthetics. The patient signed the Informed Consent Form agreeing with the beginning of the treatment and the use of the data. The patient reported psychological discomfort due to the presence of fractured restorations and stains and expressed the desired to improve her smile.

During anamnesis, a detailed medical and social history was obtained. The patient reported that her mother had had medical problems during pregnancy and that she was a preterm baby with low birth weight that had to be treated with antibiotics in early life. The patient reported not remembering to have suffered either local traumas in primary teeth or any childhood diseases. Besides, the contact with fluoride was restricted to toothbrushing with fluoridated toothpaste and using fluoridated drinking water.

The intraoral examination revealed a general failure of restorations throughout the dentition (Figure 1A). Enamel buccal stains and defects were observed on the mandibular left central incisor (Figure 1B). The patient reported having similar spots to those in the maxillary left and right central incisors and that these had been previously restored (Figure 1C). The mandibular first molars presented loss of enamel, stains, hypomineralization areas, deficient restorations, and caries lesions on the occlusal and buccal surfaces, as well as on cusp tips (Figure 1D). However, the functional analysis revealed Angle Class I relationship in both molar and canine, as well as preserved vertical dimension of the occlusion. Thus, the deficient restorations of maxillary and mandibular first molars were replaced with resin composite (Opallis ${ }^{\mathrm{TM}}$ ) as the definitive treatment. Due to the clinical appearance of the defects and the medical history, the diagnosis suggested was $\mathrm{MIH}^{5-7}$
Figure 1 - A: The initial appearance of patient; B- D: Teeth affected by $\mathrm{MIH}$

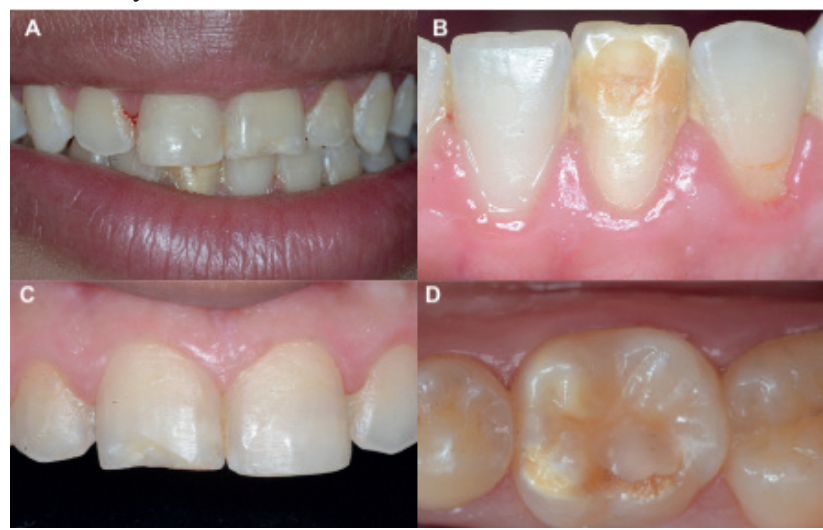

Source: The authors.

An esthetic evaluation of the patient was also performed. This evaluation included mounted models, radiographs, a complete series of intra- and extraoral photographs, color registration obtained by color scale (Vita Classical $\left.{ }^{\mathrm{TM}}\right)(\mathrm{A} 3,5)$ and an esthetic evaluation form. ${ }^{9,13,16,17}$.

The facial analysis revealed a symmetric facial midline, which corresponded to the maxillary dental midline, interpupillary line parallel to the intercommissural line, and normal lips (Figure 2A). In symmetrical faces, the interpupillary line should be parallel to the commissure line and perpendicular to the midline. ${ }^{16,18}$ During the esthetic analysis of teeth, disharmony in smile appearance was observed. The maxillary anterior teeth exhibited a darker color, short crowns, different heights of incisal edges, and different mesio-distal widths between analogous teeth, in addition to stained and/or fractured restorations (Figure 2B). In an esthetic smile, the incisal edges of the maxillary anterior teeth should follow a somewhat convex course that coincide with the curvature of the lower lip. ${ }^{16,19}$ The incisal edge curvature should be parallel to and just above the level of the lower lip. For a moderate smile, the lateral incisors should ideally remain at the distance of 0.5-1.5 mm from the lower lip, whereas the central incisors and canines should be in close relationship with the lower lip line. ${ }^{19}$ These characteristics were not observed in the present case. Young people usually display their upper teeth, so in this case, the patient's teeth should be lengthened. ${ }^{18}$ Asymmetrical gingival contour and zeniths were observed as well. The ideal harmony of this specific region should be recovered before the restorative treatment. ${ }^{18}$ Moreover, generalized gingivitis, bacterial plaque, and bleeding on probing were observed. In order to re-establish the healthy oral environment, oral hygiene instructions were provided, localized scaling was performed, carious cavities were restored with glass ionomer (Maxxion $\mathrm{R}^{\mathrm{TM}}$ ), and the maxillary anterior tooth was restored with resin composite (Opallis ${ }^{\mathrm{TM}}$ ), which improved the immediate esthetics.

In order to plan, the DSD associated with diagnostic waxup of the study model, anatomic mock-up, and temporization allowed the tridimensional visualization of the treatment proposed, 
effective communication among dentists, ceramists, and patients, resulting in greater outcome predictability., ${ }^{4,11,14,18}$ For this purpose, study models were mounted in centric relation and teeth were measured by compass (Table 1 and Figure 2C) to determine the size of the anterior teeth and with a calibrated virtual digital ruler.

Figure 2 - A: Facial analysis; B: The maxillary anterior teeth exhibiting a darker color, short crowns, different proportions between analogous teeth and stained and/or fractured restorations $\mathrm{C}$ : Teeth analysis

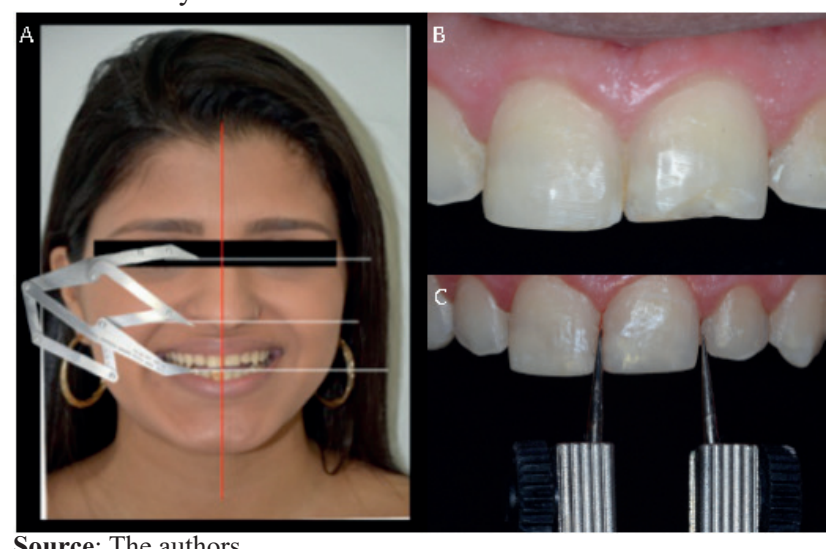

Source: The authors

Table 1 - Real measures of the teeth (length and width).

\begin{tabular}{|l|l|l|}
\hline \multicolumn{1}{|c|}{ Tooth } & \multicolumn{1}{c|}{ Inicial Length } & Initial Width \\
\hline $\begin{array}{l}\text { Maxillary right } \\
\text { lateral incisor }\end{array}$ & $\begin{array}{l}\text { Incisal- mesial- } 7.5 \mathrm{~mm} \\
\text { Incisal- distal- } 7.5 \mathrm{~mm} \\
\text { Incisal- middle- } 8.0 \mathrm{~mm}\end{array}$ & Width- $7.0 \mathrm{~mm}$ \\
\hline $\begin{array}{l}\text { Maxillary right } \\
\text { central incisor }\end{array}$ & $\begin{array}{l}\text { Incisal- mesial- } 9.25 \mathrm{~mm} \\
\text { Incisal- distal- } 9.25 \mathrm{~mm} \\
\text { Incisal- middle- } 9.25 \mathrm{~mm}\end{array}$ & Width- $9.5 \mathrm{~mm}$ \\
\hline $\begin{array}{l}\text { Maxillary left } \\
\text { central incisor }\end{array}$ & $\begin{array}{l}\text { Incisal- mesial- } 9.0 \mathrm{~mm} \\
\text { Incisal- distal- } 9.0 \mathrm{~mm} \\
\text { Incisal- middle- } 9.0 \mathrm{~mm}\end{array}$ & Width- $9.5 \mathrm{~mm}$ \\
\hline $\begin{array}{l}\text { Maxillary left } \\
\text { lateral incisor }\end{array}$ & $\begin{array}{l}\text { Incisal- mesial- } 5.5 \mathrm{~mm} \\
\text { Incisal- distal- } 6.0 \mathrm{~mm} \\
\text { Incisal- middle- } 7.0 \mathrm{~mm}\end{array}$ & Width- $6.0 \mathrm{~mm}$ \\
\hline
\end{tabular}

Then, the measurements were transferred from the tooth to the pictures to visualize the difference required in width and length (Figure 3A). The newly established incisal edge and gingival contour dictated the design of the restorations in order to better assess the esthetic relationships among teeth, gingiva, smile, and face ${ }^{9,10}$ (Table 2 and Figure 3B). After digital planning and digital simulation of the final results (Figure 3C), changes were proposed to the patient and treatment began after her consent. The desired smile design was communicated to the laboratory technician and all measurements were transferred to the study model for a diagnostic wax-up. In this case, the shape, length, and emergence profile of the teeth were modified (Figure 3D). The wax-up served as a clear vision of the anticipated smile design, added predictability to the treatment, and served as a template for the temporary restoration.

Figure 3 - A-C: Treatment plan using DSD technique; D: Diagnostic wax up

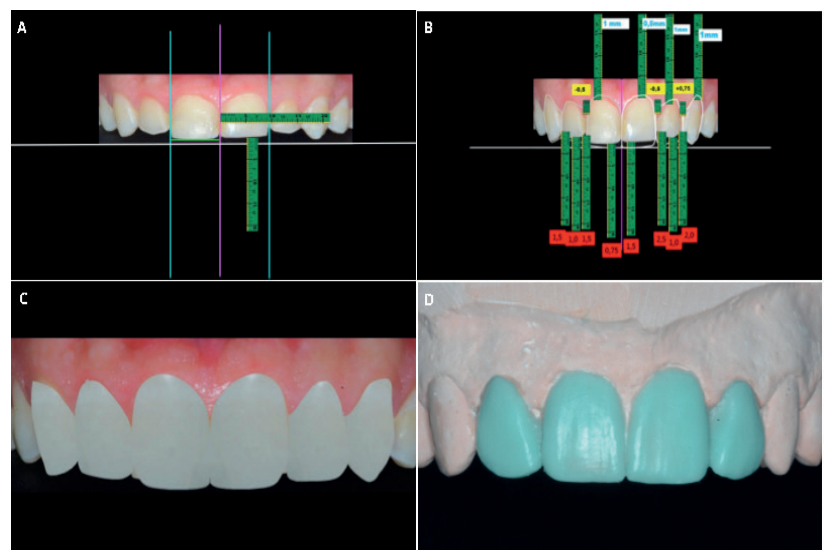

Source: The authors.

Table 2 - Incisal edge and gingival contour dictated the design of the restorations in order to make a better assessment of the esthetic relations among the teeth, gingiva, smile and face.

$\mathrm{IME}=$ Incisal mesial; $\mathrm{ID}=$ incisal distal; $\mathrm{IMI}=$ incisal middle; $\mathrm{DW}=$ distal width

\begin{tabular}{|c|c|c|c|c|c|c|}
\hline Tooth & Initial length & $\begin{array}{l}\text { Initial } \\
\text { Width }\end{array}$ & Gingivectomy & $\begin{array}{l}\text { DSD incisal/ } \\
\text { distal }\end{array}$ & Final Length & Final Width \\
\hline $\begin{array}{l}\text { Maxillary right } \\
\text { lateral incisor }\end{array}$ & $\begin{array}{l}\text { IME: } 7.5 \mathrm{~mm} \\
\text { ID: } 7.5 \mathrm{~mm} \\
\text { IMI: } 8.0 \mathrm{~mm}\end{array}$ & $7.0 \mathrm{~mm}$ & 0 & $\begin{array}{l}\text { IME: }+1.5 \mathrm{~mm} \\
\text { ID: }+1.5 \mathrm{~mm} \\
\text { IMI:+1.0 mm } \\
\text { DW: }-0.2 \mathrm{~mm}\end{array}$ & $9.0 \mathrm{~mm}$ & $\begin{array}{l}6.8 \mathrm{~mm} \\
\text { Proportion } \\
75 \%\end{array}$ \\
\hline $\begin{array}{l}\text { Maxillary right } \\
\text { central } \\
\text { incisor }\end{array}$ & $\begin{array}{l}\text { IME: } 9.25 \mathrm{~mm} \\
\text { ID: } 9.25 \mathrm{~mm} \\
\text { IMI: } 9.25 \mathrm{~mm}\end{array}$ & $9.5 \mathrm{~mm}$ & $1.0 \mathrm{~mm}$ & $\begin{array}{l}\text { IME: }+0.75 \mathrm{~mm} \\
\text { ID: }+0.75 \mathrm{~mm} \\
\text { IME: }+0.75 \mathrm{~mm} \\
\text { DW: }-0.5 \mathrm{~mm}\end{array}$ & $11.0 \mathrm{~mm}$ & $\begin{array}{l}9.0 \mathrm{~mm} \\
\text { Proportion } \\
81 \%\end{array}$ \\
\hline $\begin{array}{l}\text { maxillary left } \\
\text { central } \\
\text { incisor }\end{array}$ & $\begin{array}{l}\text { IME: } 9.0 \mathrm{~mm} \\
\text { ID: } 9.0 \mathrm{~mm} \\
\text { IMI: } 9.0 \mathrm{~mm}\end{array}$ & $9.5 \mathrm{~mm}$ & $0.5 \mathrm{~mm}$ & $\begin{array}{l}\text { IME: }+1.5 \mathrm{~mm} \\
\text { ID: }+1.5 \mathrm{~mm} \\
\text { IME: }+1.5 \mathrm{~mm} \\
\text { DW: }-0.5 \mathrm{~mm}\end{array}$ & $11.0 \mathrm{~mm}$ & $\begin{array}{l}9.0 \mathrm{~mm} \\
\text { Proportion } \\
81 \%\end{array}$ \\
\hline $\begin{array}{l}\text { maxillary left } \\
\text { lateral } \\
\text { incisor }\end{array}$ & $\begin{array}{l}\text { IME: } 5.5 \mathrm{~mm} \\
\text { ID: } 6.0 \mathrm{~mm} \\
\text { IMI: } 7.0 \mathrm{~mm}\end{array}$ & $6.0 \mathrm{~mm}$ & $1.0 \mathrm{~mm}$ & $\begin{array}{l}\text { IME: }+2.5 \mathrm{~mm} \\
\text { ID: }+2.0 \mathrm{~mm} \\
\text { IMI: }+1.0 \mathrm{~mm} \\
\text { DW: }+0.8 \mathrm{~mm}\end{array}$ & $9.0 \mathrm{~mm}$ & $\begin{array}{l}6.8 \mathrm{~mm} \\
\text { Proportion } \\
75 \%\end{array}$ \\
\hline
\end{tabular}


Considering the final cost of the treatment, it was decided not to include canine Angle Class I in the treatment plan. Nevertheless, for the maxillary left canine, gingivectomy of $1.0 \mathrm{~mm}$ was planned, so that the gingival zenith would be at the same height as that of its counterpart.

The primary aim of periodontal therapy is to maintain the tissues healthy, but this was not sufficient from the esthetic perspective, therefore, a periodontal plastic surgery was performed to optimize the gingival contour. After 21 days from (period required for gingival healing), dental bleaching using a combined technique that included two sessions of inoffice bleaching (35\% hydrogen peroxide) and 2 weeks of athome bleaching (carbamide peroxide $16 \%$ for 4 hours per day) was carried out followed by dental re-anatomization using resin composite. ${ }^{4,14,20}$ Then, the teeth were prepared to receive porcelain veneers (Figure 4A). A 4138 chamfer diamond bur was selected for the preparation. Only the maxillary central incisors were prepared and the buccal surface was reduced to an average depth of $0.7 \mathrm{~mm}$, leaving more than $80 \%$ of the substrate and more than $90 \%$ of the margin in the enamel, with 0.2-mm intrasulcular extension due to teeth discoloration. The same diamond bur was used to prepare the gingival margin, in which the reduction was slightly lower because of the small enamel thickness in this area. The removal of old composite resulted in a reduction of $2.0 \mathrm{~mm}$ in the incisal edge. A 2200 diamond bur was used to remove the contact points because of the change in the mesio-distal width measurements, and a butt-joint margin was created at the incisal line angle. The final preparation presented a chamfered margin with rounded edges. The preparation was finished with a 4138 fine-grained chamfer diamond bur. Only the proximal restorations of the maxillary left lateral incisor were removed and the maxillary right lateral incisor was not prepared (Figure 4B).

Figure 4 - A: Preparing for veneers; B: Final teeth preparation; $\mathrm{C}$ : impression of prepared teeth; D: Temporary restoration

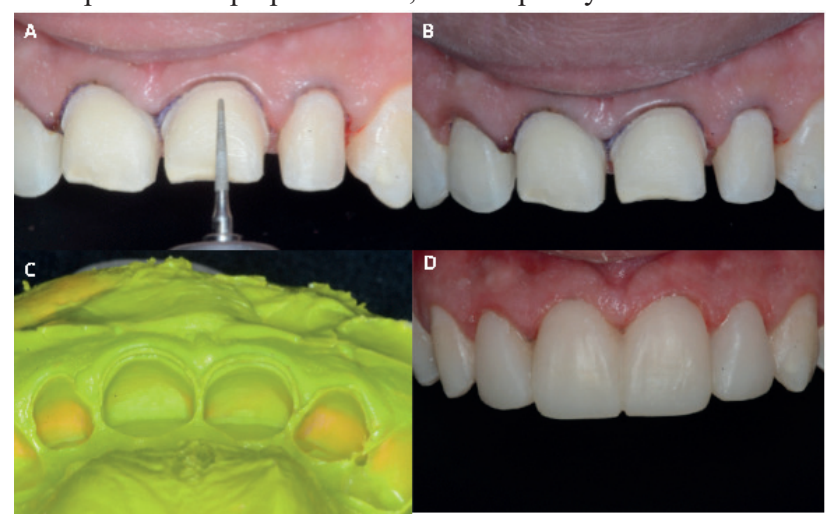

Source: The authors.

For the impression of prepared teeth, a retraction cord (Ultrapack) and a polyvinylsiloxane-based impression material (HydroXtreme ${ }^{\mathrm{TM}}$ ) were used (Figure 4C). Maximum intercuspal (centric occlusion) bite was recorded. The maxillary and mandibular casts were sent to the dental technician for the mapping of color, opacity, and translucence of the teeth.

Finally, a template obtained from the diagnostic wax-up was filled with bis-acryl resin, shade A2 (Structur 2 SC ${ }^{\text {TM}}$ ), in order to obtain a temporary restoration (Figure 4D). After adjustment and approval, an accurate impression and photographs were taken, and the laboratory was instructed to follow all the parameters of the temporaries for the final restoration. ${ }^{20}$

Before luting procedures and after the inspection of the porcelain veneers (IPS emax Press ${ }^{\mathrm{TM}}$ ) the Try-in paste of the Variolink Veneer ${ }^{\mathrm{TM}}$ luting system was used. Shade A2 was selected for the procedure, because the porcelain veneers were extremely thin ${ }^{20}$ (Figure 5A) and the luting agent color might interfere with the final result of the restoration. ${ }^{21}$ For cementation, the internal surface of the veneers was etched with $10 \%$ hydrofluoric acid (Condac porcelana ${ }^{\mathrm{TM}}$ ) for $20 \mathrm{~s}$. After washing and air-drying, post-etching cleaning was performed using 37\% phosphoric acid (Condac $37^{\mathrm{TM}}$ ) for $30 \mathrm{~s}$, followed by washing and silane application (Prosil ${ }^{\mathrm{TM}}$ ). Silane primer was placed in the internal surface of the veneers and allowed to air-dry. ${ }^{18} \mathrm{~A}$ bonding agent (Excite ${ }^{\mathrm{TM}} \mathrm{F}$ ) was applied and the solvent was allowed to evaporate for $30 \mathrm{~s}$. During dental treatment, the adjacent teeth were protected with a Tiger tape. The teeth were etched with $37 \%$ phosphoric acid gel for $30 \mathrm{~s}$ on enamel and $15 \mathrm{~s}$ on dentin, then rinsed with water for $30 \mathrm{~s}$ and dried with absorbent paper. Next, two coats of the bonding agent were applied, followed by evaporation with air spray. ${ }^{22}$ The restorations were then loaded with the luting agent (variolikVeneer ${ }^{\mathrm{TM}}$ ) and seated on the teeth. A small brush and floss were used to remove the excess cement before light curing for $40 \mathrm{~s}$ (RADII CAL ${ }^{\mathrm{TM}}$ ). A final verification of the occlusion was made with articulation paper (Accufilm). Finishing and polishing were performed with abrasive rubbers (Cerapol Plus ${ }^{\mathrm{TM}}$ ). The difference between initial and the final result achieved in this case shows what may be accomplished using a systematic interdisciplinary approach assisted by DSD (Figures 5B and 5C).

Figure 5 - A: Porcelain veneers; B: The initial appearance of patient; C: Final result.
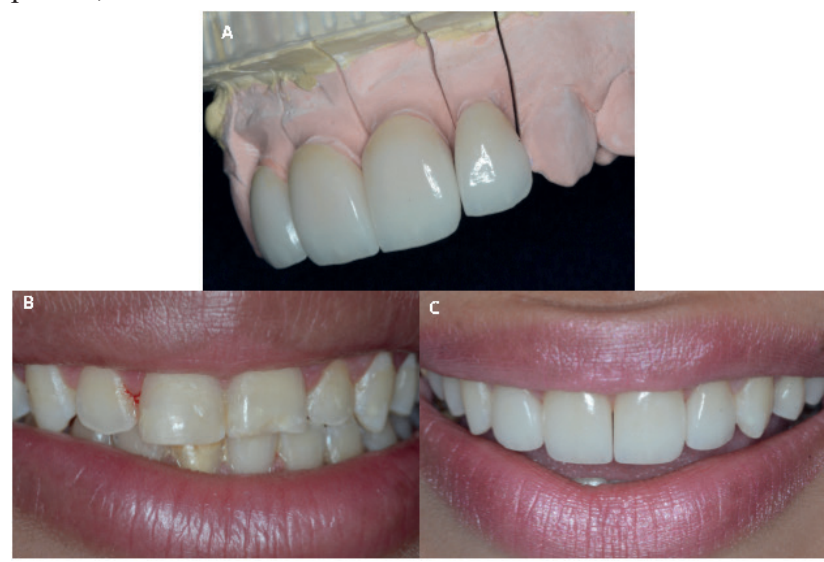

Source: The authors. 


\subsection{Discussion}

The current socioeconomic and cultural point of view on esthetic standards establishes that people will be better accepted if their teeth are aligned in the arches, with a lighter color and harmonious contacts and contours. ${ }^{19}$ The developmental disturbances of enamel are presented as structural anomalies that result from the action of various etiological factors during the enamel apposition and mineralization stages, leading to changes in shape, color, and contour of the teeth, and severely compromising esthetics. ${ }^{1,8,12,23}$ Although the clinical characteristics may be similar, the etiological factors diverges. ${ }^{5-7}$ There were some evidences suggesting that medical problems during pregnancy, childhood illnesses, or treatment with antibiotics may represent causative factors. Although a number of putative factors have been investigated, the etiology of MIH remains unclear. The teeth affected show clearly demarcated opacities on the occlusal and buccal aspects of the crown and the defects vary in color and size, as seen in the clinical case hereby presented. Severely affected enamel subjected to masticatory forces soon breaks down, leading to unprotected dentin, tooth sensitivity, and caries development. ${ }^{5-7}$

The esthetic appearance is the main reason why patients with color changes seek dental therapy.,14,20-25 Treatment planning involves different factors such as severity and type of the alteration, whether or not malocclusion is present, age and socioeconomic situation of patients, and gingival health. ${ }^{9,12,23}$ Therefore, it is extremely important for a multidisciplinary team to participate in the evaluation, diagnosis, and combination of surgical/restorative techniques to resolve the esthetic and functional changes,,${ }^{9,10,13}$ particularly in more complex clinical cases such as the one presented in this article.

Once the alteration was diagnosed, the treatment plan was established in accordance with the patient's reality and wishes. Several treatment alternatives are recommended for MIH and one possibility addresses surgical procedures that imply the wear of dental structure and restoration by composite resins, veneers or ceramic crowns. In the case presented, it was decided to adopt a cheaper and conservative approach to the posterior teeth. Thus, the elected treatment was performed direct restorations on the occlusal surfaces of the lower and upper molars since there was no need to recover the vertical dimension of the patient.

The smile design refers to the various artistic and scientific principles that, when considered collectively, may create a beautiful smile, provided they are used in compliance with the esthetic principles of symmetry, ratio, and balance., ${ }^{2,14,15}$ It should integrate the esthetic functional and emotional characteristics of the patient ${ }^{8}$ by using all the possible tools for visualizing the esthetic problem, creating possible solutions and presenting them to patients, and guiding the clinical laboratory procedures for achieving the result planned. ${ }^{4,9,10,13}$ Thus, the main advantages of using digital resources are the predictability of treatment, improvement and simplification of teamwork, and communication with the patient and laboratory. ${ }^{9,10,13}$ For this purpose, a complete dentofacial analysis should be made, following a specific evaluation sequence on the relationship among teeth, gingiva, smile, and face, by means of digital photographs worked on the computer. ${ }^{17}$ At a more advanced stage, the markings of the DSD may be transferred to the study model so to produce the diagnostic wax-up as a guide to the restorative treatment to be performed, after the necessary surgical and periodontal procedures and dental bleaching, if needed. . $^{4,914,15}$

The great diversity of esthetic restorative techniques available appeared due to the advances of dental materials, which irrespective of direct or indirect application purposes, currently provide safe and conservative treatments of long durability. ${ }^{4,20}$ In addition, it is important for the scope of planning to include stages of prevention, maintenance, and of procedures to be performed prior to the restorative treatment. These may include treatment methods for correcting gingival contour imperfections, such as periodontal plastic surgery, to return the gingival aesthetic harmony. ${ }^{13}$ Gingival esthetics relies on achieving a balance of gingival levels from the central incisors to the canines. The excess of gingival tissue, in this case, was corrected using resective periodontal surgery techniques such as gingivectomy. ${ }^{19}$

After 21 days following surgery, dental bleaching was used to achieve a lighter reference tooth color, aiming to provide the future restoration with a more natural appearance..$^{4,14,20}$ Thus, in order to soften the color difference between stained and healthy enamel, immediate external bleaching associated with home bleaching was performed. ${ }^{26-29}$ Bleaching treatment is a more conservative method compared with other methods used for treating discoloration. Office-type whitening treatment is one of the most popular methods. It involves the application of $25 \%-40 \%$ hydrogen peroxide or $16 \%-35 \%$ carbamide peroxide on the external surface of the teeth. The bleaching mechanism works on the principle that hydrogen peroxide penetrates the tooth and generates free radicals that oxidize the organic stains. ${ }^{28}$ However, tooth whitening was not enough to solve the present case, due to the misaligned shape of the teeth, requiring the use of more invasive restorative techniques to restore smile harmony.

The restorative materials used to modify the dental component of the smile include either dental composite resins or dental ceramics. ${ }^{4,14,15,20,21}$ Ceramics have come a long way after their introduction in regards to esthetic and physical properties. The extremely esthetic dental ceramics have the potential to reproduce translucence/opacity and variation in color, texture, and brightness of natural teeth. ${ }^{18,24}$ Their surface is extremely smooth, preventing the adherence of exogenous pigments. As a result of their development, it was possible to produce ceramic veneers or contact lenses for anterior 
teeth with a thickness of up to $0.2 / 0.3 \mathrm{~mm}$. Thus, esthetic corrections are possible with extremely conservative dental preparation or even without any type of preparation. ${ }^{4,15,20}$

Newly developed pressable lithium disilicate-reinforced glass ceramics, such as the IPS emax Press ${ }^{\mathrm{TM}}$ system, has become the ceramic of choice for many dentists due to the satisfactory marginal fit and improved physical properties, such as higher biaxial and fracture strength and preservation of esthetic characteristics, which precisely indicate them for the fabrication of ceramic veneers. ${ }^{4,24}$ This is an etchable ceramic composed of $70 \%$ of lithium disilicate crystals. Its composition includes two crystalline phases and one glass phase. The main crystalline phase is formed of elongated lithium disilicate crystals and the second phase is composed of lithium orthophosphate. The glass phase involves both crystalline phases incorporated into it. ${ }^{24}$ Besides the high flexural strength of up to $400 \mathrm{MPa}$, this system presents optical and flexural strength characteristics superior to those of IPS Empress IITM. ${ }^{25}$ It is highly versatile, with indications for virtually all clinical situations, especially such as the case presented, in which after a careful planning analysis using the DSD and diagnostic wax-up followed by temporization, it was possible to observe a satisfactory final result obtained with minimal or no tooth wear. The availability of this translucent high-strength monolithic ceramic material combined with the emerging demand for metal-free restorations is probably why the use of lithium disilicate restorations is so widespread. Therefore, extremely thin laminated veneers must have strength and esthetic appearance, which are exactly the features offered by the IPS e-max Press ${ }^{\mathrm{TM}}$ System.

\section{Conclusion}

A treatment plan which rises from an initial shared diagnosis is important in interdisciplinary cases. This allows the specialists to define the different points of view and better understand the competency fields, so as to plan the right sequence time for the treatment, targeting treatment to rehabilitate specific pathogens, as in the case of MIH. An ideal esthetic treatment should simultaneously promote optimum shape and function of teeth and tissues while recovering the beauty of the smile without compromising oral health and tooth stability. The DSD is an important tool for the effective development of the dental treatment. Each tool has its function and, when combined, they provide a customized treatment, respecting the desires and characteristics of each patient.

\section{References}

1. Taki AA, Mohammed TH, Hamdan AM. Influence of the smile line on smile attractiveness in short and long face individuals. Int J Dent 2017;2017:1-7. doi: https://doi. org/10.1155/2017/2637148

2. Kalia A, Mirdehghan N, Khandekar S, Patil W. Multidisciplinary approach for enhancing orthodontic estheticscase report. Clin Cosmet Investig Dent 2015;7:83-9. doi: 10.2147/CCIDE.S84401
3. Calamia JR, Wolff MS. The components of Smile Design. New York University smile evaluation form revisited, update. Dent Clin North Am 2015;59(3):529-46. doi: 10.1016/j. cden.2015.03.013

4. Meereis CTW, de Souza GBF, Albino LGB, Ogliari FA, Piva E, Lima GS. Digital Smile Design for computer -assisted esthetic rehabilitation: Two- year follow-up. Oper Dent 2016;41(1):13-22. doi: https://doi.org/10.2341/14-350-S

5. Negre-Barber A, Montiel-Company JM, Cataalá-Pizarro M, Almerich-Silla JM. Degree of severity of molar incisor hypomineralization and its relation to dental caries. Sci Rep 2018;8:1248. doi: 10.1038/s41598-018-19821-0

6. Garot E, Couture-Veschambre C, Manton D, Beauval C, Rouas P. Analytical evidence of enamel hypomineralisation on permanent and primary molars amongst past populations. Sci Rep 2017;7:1712. doi: 10.1038/s41598-017-01745-w

7. Buchgraber B, Kqiku L, Ebeleseder K. Molar Incisor hypomineralization: proportion and severity in primary public school children in Graz, Austria. Clin Oral Investig 2018;22:757-62. doi: 10.1007/s00784-017-2150-y.

8. Leevailoj C, Lawanrattanakul S, Mahatumarat K. Amelogenesis Imperfecta: Case Study. Oper Dent 2017;42(5):457-69. doi: 10.2341/13-256-S

9. Taki AA, Hamdan AM, Mustafa Z, Hassan M, Abu-Alhuda S. Smile esthetics: Impact of variations in the vertical and horizontal dimensions of the maxillary lateral incisors. Eur J Dent 2017;11(4):514-20. doi: 10.4103/ejd.ejd_351_16.

10. Frizzera F, Tonetto M, Cabral G, Shibli JA, Marcantonio JR E. Periodontics, Impantology, and Prosthodontics Integrated: The Zenith- driven Rehabilitation. Case Reports in Dentistry 2017;2017:1070292. doi: 10.1155/2017/1070292.

11. Santos FR, Kamarowski SF, Lopez CAV, Storrer LM, Teixeira Neto A. Deliberador TM. The use of the digital smile design concept as an auxiliary tool in periodontal plastic surgery. Dent Res J 2017;14(2):158-61.

12. Ayyildiz E, Tan E, Keklik H, Demirtag Z, Celebi AA, Pithon MM. Esthetic impact of gingival plastic surgery from the dentistry students' perspective. Eur J Dent 2016;10(3):397402. doi:[10.4103/1305-7456.184164]

13. Zanardi PR, Zanardi RLR, Stegum RC, Sesma N, Costa B, Laganá DC. The use of digital smile design concept as na auxiliary tool in aesthetic rehabilitation: A case report. Open Dent J 2016;10:28-34. doi:10.2174/1874210601610010028

14. Pereira LM, Tavares LN, Maruki AY, Prudente MS, Raposo LH. Esthetic rehabilitation of smile with minimally invasive preparations and thin laminate ceramic veneers using chairside CAD/CAM system. J Dent Health Oral Disord Ther 2017;8(1):00267. doi:10.15406/jdhodt.2017.08.00267

15. Alberton SB, Alberton V, Carvalho RV. Providing a harmonious smile with laminate veneers for a patient with peg-shaped lateral incisors. J conserv Dent 2017;20(3):210-3.

16. Ward DH. Proportional smile design: Using the recurring esthetic dental proportion to correlate the widths and lengths of the maxillary anterior teeth with the size of the face. Dent Clin North Am 2015;59(3):623-38. doi: 10.1016/j. cden.2015.03.006.

17. Lin WS, Harris BT, Phasuk K, Llop DR, Morton D. Integrating a facial scan, virtual smile design, and $3 \mathrm{D}$ virtual patient for treatment with CAD-CAM ceramic veneers: a Clinical report. J Prosthet Dent 2018;119(2):200-5. doi: 10.1016/j. prosdent.2017.03.007 
18. Machado AW. 10 Commandments of smile esthetics. Dental Press J Orthod 2014;19(4):136-57. doi: 10.1590/21769451.19.4.136-157.sar

19. Jafari K, Bagheri A, Hekmatfar, Dadgar L. The effect of anterior teeth forms in smile esthetics. J Interdiscipl Med Dent Sci 2017;5(4):1000217. doi: 10.4172/2376-032X.1000217

20. Rotoli BT, Lima DANL, Pini NP, Aguiar FHB, Pereira GDS, Paulillo LAMS. Porcelain veneers as an alternative for esthetic treatment: Clinical Report. Oper Dent 2013;38(5):459-66. doi: $10.2341 / 12-382-\mathrm{T}$

21. Hernandes DKL, Arrais CAG, Lima E, Cesar PF, Rodrigues JA. Influence of resin cement shade on the color and translucency of ceramic veneers. J Appl Oral Sci 2016;24(4):391-396. doi: $10.1590 / 1678-775720150550$

22. García-Sanz V, Paredes-Gallardo V, Mendonza-Yero O, Carbonell-Leal M, Albaladejo A, Montiel- Company JM et al. The effects of lasers on bond strength to ceramic materials: A systematic review and meta-analysis. PLoS One 2018;13(1):e01900736. doi:10.1371/journal.pone.0190736

23. Seow WK. Developmental defects of enamel and dentine: challenges for basic science research and clinical management. Aust Dent J 2014;59(1) 143-154. doi:10.1111/adj.12104

24. Giraldo TC, Villada VR, Castillo MP, Gomes OMM, Bittencourt BF, Dominguez JA. Active and passive application of the phosphoric acid on the bond strength of lithium disilicate. Braz Dent J 2016;27(1):90-4. doi: 10.1590/0103-6440201600428

25. Santos MO, Amaral FLB, França FMG, Basting RT. Influence of translucence/opacity and shade in the flexural strength of lithium disilicate ceramics. J Conserv Dent 2015;18(5):3948. doi:10.4103/0972-0707.164053

26. Rodrigues JL, Rocha PS, Pardim SLS, Machado ACV, FariaE-Silva AL, Seraidarian PI. Association between in-office and at-home tooth bleaching: a single blind randomized clinical trial. Braz Dent J. 2018;29(2):133-39. doi:10.1590/01036440201801726

27. de Geus JL, Wambier LM, Kossatz S, Loguercio AD, Reis A. At-home vs in-office bleaching: a systematic review and metaanalysis. Oper Dent 2016;41(4):341-56. doi:10.2341/15-287LIT

28. Faus-Matoses V, Palau-Martínez I, Amengual-Lorenzo J, Faus-Matoses I, Faus-Llácer VJ. Bleaching in vital teeth: Combined treatment vs in-office treatment. J Clin Exp Den. 2019;11(8):e754-e58. doi: 10.4317/jced.56079

29. Espíndola-Castro LF, de Melo Monteiro GQ, Ortigoza LS, da Silva CHV, Souto-Maior JR. Multidisciplinary Approach to Smile Restoration: Gingivoplasty, Tooth Bleaching, and Dental Re-anatomization. Compend Contin Educ Dent 2019;40(9):590-9. 